\title{
The Demographic Situation in Fieri Region
}

\author{
Phd. Adela Dhromaj \\ Geography Department, Faculty of Education and Social Sciences, "Eqrem Çabej" University, Gjirokastër \\ Email: adelaqalliaj@yahoo.com
}

\section{Doi:10.5901/ajis.2016.v5n3s1p151}

\section{Abstract}

The population in the Fier region during the transition period went through a lot of changes. Such changes were accompanied by economic, social and political processes which were inevitably marked by the intra-regional specifications of the region. According the statistics, the population in this region after the year of 1990 experienced a decrease of about $1.3 \%$ compared with the previous period. This situation is due to two reasons: the decrease in natural growth (reduced by over 3 times), and the impact of internal migration from the county mainly to the capital city of Albania but also as a result of emigration abroad. The greatest impact is a result of the reduction which is linked with a decrease in the birth rate coefficient from $24.3 \%$ (1989) to $10.1 \%$ in 2001 to $14.5 \%$ at present. Changes identified in the density of the county population. The average population density has fallen to163 h/km² in (2011) from $202 \mathrm{~h} / \mathrm{km}^{2}(1989)$. Population in the county is on average older than it was 22 years ago. The old population (+ 65 years), has increased to $12.1 \%$ from $7.1 \%$ which was in 2001 , and the reduction of the new age (1-15 years old), is greater than the increase of population over 65 years old. During its evolution, the population in this county presents differences along spatial distributionl according settlements city - village, district and municipalities. The phenomenon as analyzed according to the division between the two kinds of settlements urban-rural show that the increase in urban population is more than its natural growth and the opposite is true for the village population mainly due to the urbanization phenomenon.

Keywords: Natural growth, rate of birth, average annual growth, migration, settlement.

\section{Introduction}

After the year 1990, population in the Fier county experienced many changes which had a strong effect on both its quantitative and qualitative indicators. This paper tries to analyse and highlight the changes and trends observed in the quantitative dimension (the general number of population in the county), in the light of new socio-economic and political circumstances, which dictated the development of the Albanian society, at the end of 1980 . The Fier county consists of three districts: Fier (the county seat), Lushnje and Mallakaster.

\section{The Numerical Evolution of the Population in the Fier County During the Time Period under Discussion}

The demographic situation in this region after 1989 is inextricably related to a host of factors, such as, geographic, political, economic, social and demographic factors etc.

According to the statistics after 1990, the population in the Fier region has increased by 1.3 times compared with the year 1989 .

Table 1: The population in the Fier region (resident population), 1989-2011, in \%.

\begin{tabular}{|c|c|c|c|c|c|}
\hline \multirow{3}{*}{ Units } & \multicolumn{4}{|c|}{ Years } & \multicolumn{2}{c|}{2011} \\
\cline { 2 - 6 } & 1989 & \multicolumn{2}{|c|}{2001} & Nr. of pop. & a.a.g. ${ }^{1}$ 2001-2011 \\
\cline { 2 - 6 } & Nr. of pop. & Nr. of pop. & a.a.g. 1989-2001 & 494116 & 0.2 \\
\hline Region & 381532 & 483269 & 2.0 & 202375 & 0.8 \\
\hline Urban area & 101600 & 187126 & 5.2 & 291741 & 0.1 \\
\hline Rural area & 279932 & 296143 & 0.5 & \\
\hline
\end{tabular}

Source: INSTAT Republic of Albania Directorate of Statistics Fier, Lushnje, Mallakastër. Yearbook of statistics for the districts Fier, Lushnje, Mallakastër

${ }^{1}$ Annual average growth 


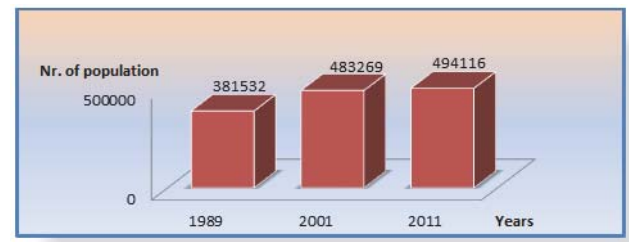

Figure 1. The evolution of the (resident) population in the Fier region (1989-2011)

Source: INSTAT Republic of Albania Directorate of Statistics Fier, Lushnje, Mallakastër. Yearbook of statistics for the districts Fier, Lushnje, Mallakastër

When this increase (by about 1.3 times) is compared with the previous statistical time period (1950-1989) we see that the increase in population is lower, at a time when the population according to the 1989 census was 3 times bigger than in the year 1950.

As a result of this situation the natural growth rate has decreased due to factors such as, the internal migration from the county to other wealthier areas primarily the capital city but also emigration abroad. In order to assess the consequences of the decrease in the natural growth rate we refer to the statistics in the following table. The natural growth rate coefficient in the year 2011 is under $6.0 \%$ (5.8\%) which is lower when compared with $19.5 \%$ that was in the year 1989. The statistics shows that this indicator during the previous period of 22 years has decreased by more than 3 times. This big decrease in birth rate coefficient from $24.3 \%$ (1989) and $14.5 \%$ (2001) to $10.1 \%$ nowadays has contributed the most to the reduction in this indicator.

Table 2. The natural growth rate of population in the Fier county (1989- 2011), in \%o

\begin{tabular}{|l|c|c|c|c|c|c|c|c|c|}
\hline & \multicolumn{9}{|c|}{ Years } \\
\hline \multirow{2}{*}{ Units } & \multicolumn{3}{|c|}{ 1989 } & \multicolumn{3}{c|}{ 2001 } & \multicolumn{3}{c|}{ 2011 } \\
\cline { 2 - 12 } & N.G. $^{2}$ & K.F. $^{3}$ & K.M. ${ }^{4}$ & N.G & K.F. & K.M. & N.G & K.F. & K.M. \\
\hline County & 19.5 & 24.3 & 4.9 & 10.7 & 14.5 & 3.8 & 5.8 & 10.1 & 4.3 \\
\hline Fier district & 19.0 & 24 & 5 & 10.8 & 14.6 & 3.8 & 4.7 & 11.7 & 4.3 \\
\hline Lushnje district & 20.0 & 24.7 & 4.7 & 9.8 & 13.7 & 3.9 & 3.2 & 7.4 & 4.2 \\
\hline Mallakastër distr. & & - & - & 13.1 & 17 & 3.9 & 6.9 & 11.2 & 4.3 \\
\hline
\end{tabular}

Source: INSTAT Republic of Albania Directorate of Statistics Fier, Lushnje, Mallakastër. Yearbook of statistics for the districts Fier, Lushnje, Mallakastër 2002- 2007-2010-2011

Table 3. The mechanical population growth rate of resident population of the Fier region (1989-2011), in \%o

\begin{tabular}{|l|c|c|c|c|c|c|}
\hline \multirow{3}{*}{ Units } & \multicolumn{6}{|c|}{ Years } \\
\cline { 2 - 7 } & \multicolumn{3}{|c|}{1989} & \multicolumn{3}{c|}{$\mathbf{2 0 0 1}$} \\
\cline { 2 - 7 } & $\mathbf{M . G ^ { 5 }}$ & K.M. $^{6}$ & K.E. $^{7}$ & M.G & K.M. & K.E. \\
\hline Region & 4.3 & 9.2 & 4.9 & -4.0 & 5.7 & 9.7 \\
\hline Fier & 5.7 & 10.0 & 4.3 & 2.2 & 6.1 & 8.3 \\
\hline Lushnje & 1.8 & 7.7 & 5.9 & 3.6 & 5.5 & 9.1 \\
\hline Mallakastër & & - & & -15.1 & 4.5 & 19.6 \\
\hline
\end{tabular}

Source: INSTAT Republic of Albania Directorate of Statistics Fier, Lushnje, Mallakastër. Yearbook of statistics for the districts Fier, Lushnje, Mallakastër. Accrued by V. Duri

\footnotetext{
${ }^{2}$ Natural growth

${ }^{3}$ Fertility Coefficient

${ }^{4}$ Mortality Coefficient

${ }^{5}$ Net Migration

${ }^{6}$ Coefficient of immigration

${ }^{7}$ coefficient of migration
} 
Statistics regarding the coefficient of migration balance is an important factor in the analysis of population decrease in the county, after 1989.

\section{The Evolution of Population in Fier Region as Seen from the Spatial Viewpoint}

\subsection{The evolution of population in Fier region according to the type of settlement (urban - rural).}

The reality observed taking into account the type of settlement is that urban population has increased at a faster pace than the natural growth rate whereas the opposite is true for the village.

According to the statistics it can be said that the general population until 2001 has increased $18.7 \%$ whereas the urban population has increased $21.4 \%$ compared with 1989. After this year, during the last two censuses population has decreased in the urban area of the county too by $0.02 \%$ on average per year compared with an increase of $1.6 \%$ in the previous period (1989-2001).

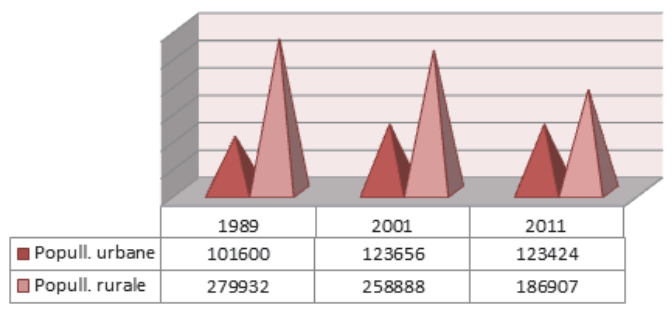

Figure 2: The population of Fier county according to the districts (1989-2011)

Source: Vjetari statistikor i RPS të Shqipërisë 1989, Tiranë, 1990; INSTAT Popullsia e Shqipërisë në vitin 2001, REPOBA Qarku Fier, Tiranë 2001; INSTAT Republika e Shqipërisë. Censusi i Popullsisë dhe Banesave, FIER 2011

\subsection{Population in Fier region based on the type of settlement (urban - rural)}

The rural population has decreased by 33.2\% (after 22 years), at an average of $3.2 \%$ per year (r.m.v. -3.2\%), which means that people have migrated more outside the county than towards its urban area (of the county), at a time when the urban population itself experienced a decrease (2001-2011).

\subsection{The evolution of the population in Fier region according to the districts.}

By analyzing the tendency of the general number of population of the county, according to the districts, it can be seen that only the populations of two districts Fier and Lushnje went through an increase. The Mallakastër district is negatively affected by an increasingly negative net migration rate coefficient.

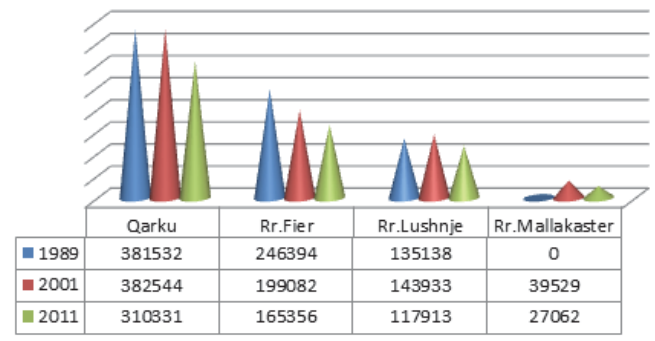

Figure 3. The population of Fier according to the districts

Source: INSTAT Popullsia e Shqipërisë në vitin 2001 REPOBA Qarku Fier, Tiranë 2001 


\subsection{According to the former municipalities}

Changes can also be seen according to the municipalities. Based on the trend of variation which the population underwent according to the municipalitites, we see that there is a decrease in population in all the municipalities although at different intensity when the last two censuses are compared. The biggest decrease in population is felt in: Levan now a subdivision of the Fier municipality (-3390 h.), Cakran also now a subdivision of the Fier municipality ( $3077 \mathrm{~h}$.) and Qëndër again a subdivision of the Fier municipality $(2523 \mathrm{~h}$.). This category of former municipalities is followed by those in which the population decrease varies from $1200 \mathrm{~b}-2260 \mathrm{~b}$, where $50.0 \%$ of the former municipalities of the county belong to this category. Other former municipalities in which the decrease in population varies from $385 \mathrm{~h} .-1200 \mathrm{~h}$. constitute only $34.0 \%$.

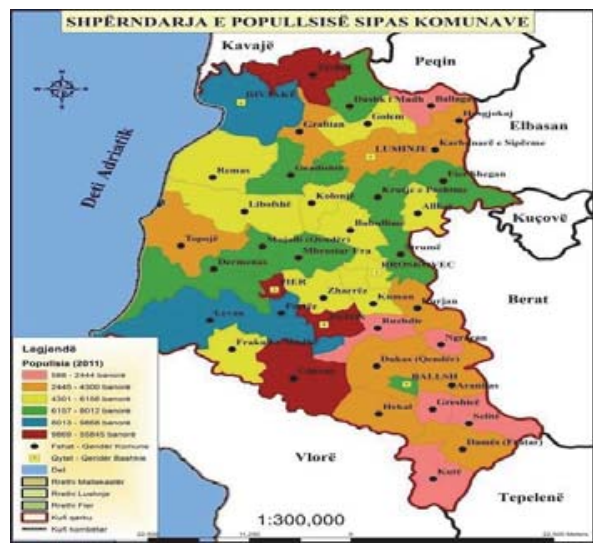

Figure 4. The map of population number in Fieri region

Source: INSTAT Republika e Shqipërisë. Censusi i Popullsisë dhe Banesave, FIER 2011, Accrued by A.Dhromaj

\section{The Population Density in Fieri Region (1989-2011)}

Population density and the rate of development of a region are important indicators of the socio-economic structure and of the demographic policy pursued by the local government as part of its ongoing effort to maintain and regulate societal issues as well as wealth distribution.

The territorial distribution of the population is a lengthy and complex historical process, shaped by such factors as, the geographic, natural, socio-economic, demographic, etc,.

Fier county with an area of 1910 square $\mathrm{km}$ constitutes about $7.0 \%$ of the entire area of The Republic of Albania and $11.1 \%$ of the Albanian population lives there, (2011), with an average population density $162.5 \mathrm{~h} / \mathrm{square} \mathrm{km}$. This fact is a clear sign of the high population density in the Fier county, compared with the average population density of The Republic of Albania $97.0 \mathrm{~h} / \mathrm{square} \mathrm{km}$, this makes Fier the third most densely populated county in Albania.

Table 4. The population density of the region by districts

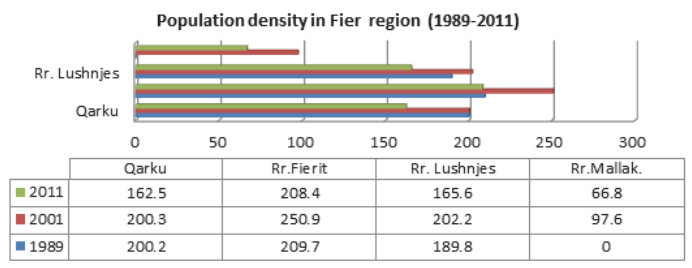

Source: INSTAT Republic of Albania Directorate of Statistics Fier, Lushnje, Mallakastër. Yearbook of statistics for the districts Fier, Lushnje, Mallakastër 1989; INSTAT Popullsise Shqipërisë në vitin 2001 REPOBA Qarku Fier, Tiranë 2001 
The population is not evenly distributed, judging by the spatial distribution of villages, districts and municipalities, etc.

- $60.0 \%$ of the county population resides in the countryside and occupies $84.4 \%$ of the area of the county, whereas about $40.0 \%$ of the populations live in the cities.

Table 5. The population distribution in Fier region (urban -rural), in (\%)

\begin{tabular}{|l|c|c|c|c|c|c|}
\hline \multirow{3}{*}{ Units } & \multicolumn{3}{|c|}{ Years } \\
\cline { 2 - 7 } & \multicolumn{2}{|c|}{1989} & \multicolumn{2}{c|}{2001} & \multicolumn{2}{c|}{2011} \\
\cline { 2 - 7 } & Surface & Pop. & Surface & Pop. & Surface & Pop. \\
\hline Region & 100.0 & 100 & 100.0 & 100 & 100.0 & 100 \\
\hline Urban area & 15.6 & 26.62 & 15.6 & 32.3 & 15.6 & 39.8 \\
\hline Rural area & 84.4 & 73.37 & 84.4 & 67.7 & 84.4 & 60.2 \\
\hline
\end{tabular}

Source: INSTAT Republic of Albania Directorate of Statistics Fier, Lushnje, Mallakastër. Yearbook of statistics for the districts Fier, Lushnje, Mallakastër 1989; INSTAT Popullsia e Shqipërisë në vitin 2001 REPOBA Qarku Fier, Tiranë 2001

After 1990, population shows a marked tendency to concentrate on the cities.

- According to the districts, $62.0 \%$ of the urban population of the county lives the city of Fier, (the biggest administrative centre of the county also the county seat) and less than (6.2\%), in the district of Mallakastër. This is directly linked with the migration of the population mainly to Fier, but also to Tirana, Durres, but also abroad.

- According to the municipalities, judging by the population rate there are differences as shown in the maps below which show population density in Fier region. 18 former communes which constitute $50.0 \%$ of the total number of former communes in the Fier region, have a lower population density than the average density of rural population of the county $\left(114 \mathrm{~h} / \mathrm{square} \mathrm{km}^{2}\right)$, at a time when the other half of the former communes have a population density above the average density of the former communes of the county.

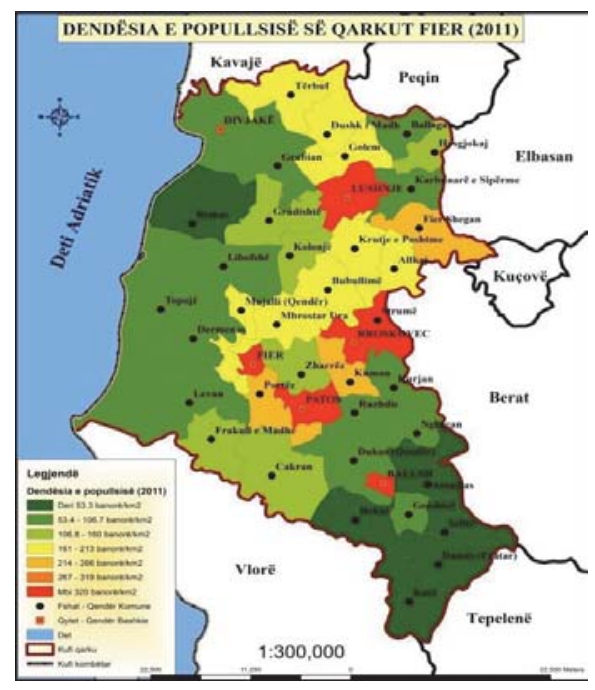

Figure 5. The map of population density in Fieri region

Source: INSTAT Popullsia e Shqipërisë në vitin 2011 REPOBA Qarku Fier, Tiranë 2011

The disparities present in the distribution of the population throughout the county area are a clear sign that the local and central government should adopt a different approach in a bid to narrow the differences between the population and the rate of development. 


\section{References}

INSTAT Popullsia e Shqipërisë në vitin 2001 REPOBA Qarku Fier, Tiranë 2001

INSTAT Republic of Albania Directorate of Statistics Fier, Lushnje, Mallakastër. Yearbook of statistics for the districts Fier, Lushnje, Mallakastër.

INSTAT Republic of Albania Directorate of Statistics Fier, Lushnje, Mallakastër. Yearbook of statistics for the districts Fier, Lushnje, Mallakastër 2002- 2007-2010-2011.

INSTAT Republika e Shqipërisë. Censusi i Popullsisë dhe Banesave, FIER 2011

Vjetari statistikor i RPS të Shqipërisë 1989, Tiranë, 1990 